\title{
HABITUASI UNTUK MENGUATKAN KARAKTER NASIONALISME PESERTA DIDIK WILAYAH PERBATASAN PADA ABAD 21
}

\author{
Fransiskus M. P. Keraf dan Kokom Komalasari \\ Universitas Pendidikan Indonesia \\ Email: keraffransiskus@gmail.com
}

\begin{abstract}
Abstrak: Penelitian ini dilatarbelakangi oleh perilaku peserta didik di wilayah perbatasan yang cenderung bersikap, berbahasa, berbudaya hingga menyukai penggunaan produk dari Timor Leste dibandingkan Indonesia. Tujuan penelitian ini untuk mendeskripsikan proses pelaksanaan penguatan karakter nasionalisme melalui pembiasaan (habituasi) di SMPN Silawan, Kabupaten Belu, Nusa Tenggara Timur. Proses penelitian menggunakan pendekatan kualitatif dengan metode deskriptif. Subjek dalam penelitian ini adalah peserta didik, guru, dan tokoh masyarakat. Teknik pengumpulan data yang digunakan yaitu observasi, wawancara, dan dokumentasi. Analisis data meliputi langkah-langkah reduksi data, penyajian, dan penarikan kesimpulan. Hasil penelitian menunjukan bahwa program pembiasaan (habituasi) yang diselenggarakan oleh sekolah, mampu untuk menguatkan karakter nasionalisme peserta didik. Hal tersebut dibuktikan oleh perilaku dan juga aktivitas sehari-hari peserta didik yang sudah mencintai produk dalam negeri, berbahasa Indonesia dengan baik, dan benar hingga merasa sangat mencitai Indonesia. Teknik yang digunakan oleh sekolah dalam menguatkan karakter nasionalisme peserta didik adalah melalui pembiasaan (habituasi). Melalui pembiasaaan ini, sekolah menyelenggarakan best practice yang meliputi upacara bendera, penggunaan bahasa Indonesia yang baik dan benar, menyanyikan lagu kebangsaan sebelum dan sesudah pembelajaran, penyambutan tamu kenegaraan di wilayah perbatasan, penggunaan yel-yel kebangsaan, dan keteladanan guru.
\end{abstract}

Kata Kunci: habituasi, karakter nasionalisme, peserta didik, wilayah perbatasan, abad 21

\section{HABITUATION TO STRENGTHEN CHARACTER OF NATIONALISM OF STUDENTS OF THE BORDER REGION IN THE 21' ${ }^{\text {ST }}$ CENTURY}

\begin{abstract}
This research is motivated by students' behavior in Indonesian border region who prefer to behave, speak, cultured even use products from Timor Leste compared to Indonesia. The purpose of this research was to describe the process of strengthening the character of nationalism through habituation in SMPN Silawan, Belu Regency, East Nusa Tenggara Province. The research process used qualitative approach with descriptive methods. The subjects in this research were students, teachers, and community leaders. Data collection used observation, interviews, and documentation techniques. The validity analysis of the data consists of data reduction, display, and conclusion drawing. The results of the study showed that through habituation programs organized by schools, it was able to strengthen the character of nationalism of students. That was proven by the behavior and daily activities of the students who have loved domestic products, speak Indonesian well and appropriate, even feel very fond of Indonesia. The technique used by schools in strengthening the character of students' nationalism was through habituation. Through this practice, the school organized best practices in program included flag ceremonies, the use of good and appropriate Indonesian language, singing national anthem before and end the learning, welcoming state guests in the border region, using national yells, and exemplary teacher.
\end{abstract}

Keywords: habituation, nationalism character, student, border area, the 21st century

\section{PENDAHULUAN}

Pendidikan merupakan suatu proses yang dilakukan manusia secara terus-menerus untuk menyempurnakan diri dari kekurangan dan keterbatasan yang dimiliki- nya (Sulistyawati, Sunnah, \& Setiawan, 2018). Sistem pendidikan tidak hanya menanamkan pengetahuan dan memupuk orang untuk menjadi warga negara yang setia, tetapi juga secara tradisional menun- 
tut kesetiaan terhadap tradisi dan budaya yang diciptakan kelompok yang dominan; serta mengindikasikan pendidikan hanyalah satu institusi yang memediasi dan mensosialisasikan individu ke dalam masyarakat dan membentuk pemahaman tentang bangsa dan masyarakat, yang terbentuk melalui berabad-abad sejarah (Hjerm, 2010).

Pendidikan di Indonesia diarahkan ke dalam pendidikan nasional yang mengembangkan kemampuan dan membentuk watak serta peradaban bangsa yang bermartabat dan mencerdaskan serta menjadi warga negara yang bertanggung jawab sesuai Undang-Undang No. 20 Tahun 2003 tentang Sistem Pendidikan Nasional. Oleh karena itu, pendidikan merupakan bagian terpenting bagi manusia untuk mendapatkan kualitas pembelajaran yang baik serta penguatan karakter diri (Hermuttaqien, Sata, \& Wadu, 2019). Karakter diri yang kuat pada seseorang, memiliki pengaruh yang besar dalam menciptakan tatanan kehidupan sosial yang baik melalui penanaman nilai pendidikan karakter di dalamnya (Kirom, 2018). Aqib \& Sujak (2011:3) menegaskan bahwa individu yang berkarakter adalah seseorang yang melakukan hal-hal yang terbaik terhadap Tuhan YME, dirinya, sesama, lingkungan, bangsa, dan negara serta dunia internasional pada umumnya dengan mengoptimalkan potensi (pengetahuan) dirinya dan disertai dengan kesadaran, emosi, dan motivasinya (perasaannya). Taufik (2014) beralasan bahwa sesungguhnya yang menentukan bagi kemajuan suatu bangsa adalah kualitas karakter masyarakatnya, karena bangsa yang memiliki kualitas karakter baik akan mampu menggerakkan seluruh area aktivitas, di antaranya dapat meningkatkan semangat bersaing, meningkatkan kualitas personal, meningkatkan kolaborasi antarpribadi, dan seterusnya sehingga karakter yang baik akan membawa pada perubahan di seluruh aspek kehidupan.

Mulyasa (2015:19) menyatakan bahwa revolusi mental di sekolah harus menyentuh persoalan bagaimana membangun manusia yang berkualitas dan berkarakter secara kaffah, yakni tidak hanya menjadi ajang pengembangan intelektual, tetapi membangun karakter manusianya, jiwa dan qolbunya. Selanjutnya, Muslich (2013: 47) menegaskankan bahwa mendidik tidak hanya mentransfer ilmu saja, melainkan yang lebih utama adalah dapat mengubah atau membentuk karakter dan watak seseorang agar menjadi lebih baik, lebih sopan dalam tataran etika maupun estetika serta berperilaku dalam kehidupan sehari-hari.

Karakter masyarakat di wilayah perbatasan mempunyai pengaruh tertentu pada kehidupan ekonomi dan sosial penduduk di kedua sisi perbatasan (Bański \& Janicki, 2013). Jika bangsa asing menganggap negara sebagai negara kota dalam konteks yang besar, maka perbatasan adalah dindingnya (Walters, 2006). Penelitian yang dilakukan oleh Permatasari (2014) menyimpulkan bahwa masalah paling utama masyarakat yang tinggal di perbatasan adalah kesejahteraan dan kurangnya pembangunan infrastruktur, akibatnya masyarakat perbatasan tertarik untuk menyeberang ke negara lain dengan jaminan yang lebih baik, selain itu juga masyarakat perbatasan merupakan penjaga pintu perbatasan negara yang setiap saat rentan terhadap isu-isu kontemporer. Peserta didik di wilayah perbatasan memiliki banyak arti yang berbeda yang sangat bervariasi dari waktu maupun tempat, hingga mempengaruhi budaya dan bahkan bahasa yang sekaligus sebagai konstruksi sosial yang kompleks, dengan banyak arti dan fungsi berbeda yang dikenakan pada mereka (Haselsberger, 2014). 
Memasuki abad ke-21, pendidikan tidak hanya dipandang sebagai pabrik yang menghasilkan barang saja, melainkan juga sebagai lembaga yang memiliki tujuan yang sangat penting, yakni untuk memanusiakan manusia. Pandangan itu memiliki asumsi bahwa dalam implementasinya, pendidikan harus terintegrasi sepenuhnya dan memperhatikan integrasi potensi manusia, integrasi manajemen, integrasi kurikulum, integrasi domain pembelajaran, integrasi tiga pusat pendidikan, integrasi teori dan praktik, dan integrasi proses pembelajaran (Muchtarom, Budimansyah, \& Suryadi, 2016). Tuntutan abad ke-21 membutuhkan sekolah dengan guru memainkan peran penting sebagai tokoh profesional dengan pengetahuan dan pengalamannya untuk memenuhi standar tinggi dan untuk mencapai pertumbuhan dan perubahan (Holm \& Horn, 2003).

Pengajaran di abad ke-21 tidak dapat dilakukan dengan cara yang sama seperti yang dilakukan di abad pertengahan, melainkan memungkinkan semua jenis pembelajaran terjadi kapan saja, dan di mana saja. Secara khusus, semua pendidik memiliki peran penting untuk diimplementasikan dalam hal pengasuhan moral melalui empati dan kasih sayang terhadap orang lain untuk menciptakan komponen kunci dalam membangun dan mempertahankan sosialisasi antarsesama (Dyson, 2010). Peran pendidikan di abad ke-21 lebih berfungsi sebagai pengungkit dalam memfasilitasi transformasi organisasi yang terbukti menjadi salah satu intervensi paling kuat dalam mempercepat langkah dan kedalaman perubahan (Conger \& Xin, 2000). Di samping itu, kebutuhan peserta didik untuk mengetahui lebih banyak tentang budaya, agama dan realitas kehidupan orang lain, juga diperlukan di abad ini untuk mengidentifikasi dan memperkuat nilai-ni- lai yang mungkin mereka lihat di masa lalu sebagai ancaman dengan nilai-nilai yang dikuatkan sebagai bagian dari kesetiaan terhadap bangsa (Vinokur, 2018). Selain itu, stabilitas keluarga yang lebih besar juga akan mempengaruhi pendidikan anak yang lebih baik. Hal tersebut terlihat saat keluarga mengelaborasi kegiatan pengasuhan anak dan tanggung jawab ganda sebagai bentuk kepedulian terhadap pendidikan anak (Sassler, 2018).

Masyarakat yang hidup di wilayah perbatasan antara Indonesia dan Timor Leste di Kabupaten Belu, Provinsi Nusa Tenggara Timur (NTT), telah dipengaruhi oleh budaya asing 3F (food, fashion, and fun) milik Timor Leste. Peserta didik yang tinggal di daerah perbatasan hingga saat ini masih menggunakan pola-pola hidup seperti masyarakat Timor Leste pada umumnya. Selain itu, tanpa disadari peserta didik di wilayah perbatasan dengan bangganya menggunakan atribut atau identitas kepunyaan masyarakat Timor Leste. Peserta didik menggunakan topi, baju bergambar bendera Timor Leste, mengonsumsi makanan maupun minuman Timor Leste dan lebih parahnya lagi mereka akan merasa sangat bangga saat bisa berbahasa Timor Leste dengan fasih. Salah satu SMPN yang berada di wilayah perbatasan tersebut adalah SMPN Silawan. Peserta didik yang sedang memperoleh pendidikan pada sekolah ini berjumlah 312 siswa, terdiri dari 60\% siswa eks Timor Timur dan 40\% merupakan warga asli namun berketurunan Timor Timur Distrik Bobonaro (Arsip Sekolah, 2017).

Jika mencermati fenomena di atas, tentunya timbul pandangan bahwa perlunya suatu penguatan karakter nasionalisme bagi peserta didik guna menyiapkan generasi yang siap berkorban untuk bangsanya. Pureklolon (2017:35) menyatakan bahwa 
nasionalisme merupakan bentuk loyalitas terhadap negara, di mana rakyat mempunyai rasa kepemilikan untuk negaranya dan negara memiliki rakyat yang memberikan kontribusi melalui kesatuan yang kuat dari suatu negara dalam mempertahankan wilayah dan eksistensinya. Penyelundupan, belanja lintas batas atau pasar tenaga kerja, adalah contoh insentif untuk interaksi yang tidak muncul tanpa batas negara. Hal tersebut nampak jelas bahwa batas negara bukan hambatan dalam semua konteks, dan itu tidak membatasi setiap bentuk komunikasi dan interaksi (Schack, 2001; Misra, 2013). Penelitian yang dilakukan oleh Saleh (2011) mengungkapkan bahwa karakter nasionalisme menurut masyarakat perbatasan tidak lebih dari rasa yang senantiasa terpatri dalam jiwa sebagai bangsa Indonesia, di manapun dan dalam kondisi apapun.

Mencermati dinamika yang terjadi pada peserta didik di wilayah perbatasan di atas, maka perlu strategi yang dilakukan oleh sekolah pada wilayah perbatasan dalam membentuk karakter nasionalisme peserta didik melalui pembiasaan-pembiasaan (habituasi). Kementerian Pendidikan dan Kebudayaan (Komalasari \& Saripudin, 2017:100) menyebutkan bahwa habituasi sebagai pembiasaan yang artinya merupakan proses pembentukan sikap dan perilaku yang relatif menetap dan bersifat otomatis melalui proses pembelajaran yang berulang-ulang. Sahlan dan Prastyo (2017) menyatakan bahwa pembiasaan dan peniruan itu pada hakikatnya merupakan esensi dari pendidikan dalam bentuk sebuah kearifan yang harus diperkenalkan sejak dini kepada peserta didik. Guthrie (Schunk, 2012: 188) mengidentifikasi tiga metode untuk mengubah kebiasaan: ambang batas (threshold), keletihan (fatigue), dan respon yang tidak sesuai (compatible response). Lanjutnya menjelaskan bahwa ide-ide tentang meng- ubah kebiasaan juga dianggap memberi inspirasi dan memberikan tuntunan umum yang bagus bagi siapapun yang ingin mengemangkan kebiasaan yang lebih baik. Giddens (Saptono, 2011:58) menyatakan bahwa kebiasaan itu menciptakan struktur hidup sehingga memudahkan orang untuk bertindak; melalui habitus, orang tak perlu susah payah bernalar, mengambil jarak atau memberi makna setiap kali hendak bertindak. Alfiky (Anwar, 2014) mengungkapkan bahwa kebiasaan adalah suatu pola pikir yang telah tertanam dalam diri seseorang, kemudian dikorelasikan dengan keinginan untuk melakukannya secara berulang-ulang hingga akal meyakinya sebagai indikator dari perilakunya. Untuk itulah pendidikan menjadi wadah dasar untuk membiasakan civic habits sebagai persiapan untuk berkontribusi dalam kehidupan nyata (Abdillah, 2018)"

Berdasarkan paradigma dan fenomena di atas, maka penulis bermaksud untuk melakukan penelitian secara komprehensif mengenai proses penguatan karakter nasionalisme melalui program pembiasaan (habituasi) pada siswa SMPN wilayah perbatasan pada abad ke-21. Melalui kegiatan pembiasaan tersebut, maka peserta didik dapat terbentuk sekaligus dikuatkan karakter nasionalisme mereka dalam proses sosialisasi selanjutnya dalam kehidupan bermasyarakat dan bernegara.

\section{METODE}

Penelitian ini dilakukan di SMPN Silawan Kabupaten Belu Provinsi Nusa Tenggara Timur (NTT). Penelitian ini merupakan penelitian deskriptif kualitatif. Subjek penelitian ini yaitu 6 guru, 2 peserta didik, dan 1 tokoh masyarakat.

Pengumpulan data dalam penelitian ini menggunakan teknik observasi, wawancara, dan dokumentasi. Peneliti mengguna- 
kan observasi partisipan dengan peran observasional yang beruah-ubah. Creswell (2015:424) menegaskan bahwa peran partisipan yang berubah-ubah adalah peran dari peneliti yang mengadaptasikan perannya dengan situasi yang ada. Peneliti pada mulanya pergi ke tempat observasi sebagai seorang nonpartisipan, yang sekedar ingin melihat fase awal penelitian. Dalam perjalanannya, peneliti berhasil menjalin hubungan yang baik dengan subjek penelitian. Selain itu, peneliti juga melakukan wawancara. Dalam wawancara ini peneliti menggunakan teknik one on one interview atau wawancara satu lawan satu. Teknik ini bertujuan untuk mendeskripsikan proses pelaksanaan program pembiasaan (habituasi) yang diselenggarakan sekolah untuk menguatkan karakter nasionalisme peserta didik. Dalam pengumpulan data, dokumentasijuga dilakukan oleh peneliti yakni data yang terkait dengan pelaksanaan program pembiasaan di sekolah.

Data yang terkumpul kemudian dianalisis. Analisis data dilakukan dengan teknik analisis kualitatif dengan langkahlangkah reduksi data, penyajian data, dan penarikan kesimpulan atau verivikasi.

\section{HASIL DAN PEMBAHASAN}

\section{Hasil}

Hasil penelitian menunjukan bahwa ada aktivitas yang dilakukan oleh SMPN Silawan dalam menguatkan karakter nasionalisme peserta didik. Upaya penguatan yang dilakukan oleh sekolah adalah melalui program pembiasaan. Program pembiasaan tersebut diikuti secara aktif dan penuh antusias oleh peserta didik di sekolah ini. Program pembiasaan ini melibatkan seluruh stake holder sekolah tanpa terkecuali. Adanya keterlibatan yang aktif antara perangkat sekolah dan peserta didik berhasil menciptakan efektivitas pelaksanaan program pembiasaan di sekolah.
Berdasarkan hasil wawancara maka dapat disimpulkan bahwa program-program pembiasaan yang diselenggarakan di SMPN Silawan terdiri dari pembiasaan yang beraneka ragam. Program pembiasaan (habituasi) ini bertujuan untuk menguatkan karakter nasionalisme peserta didik. Adapun program-program pembiasaan tersebut yakni menyanyikan lagu wajib nasional dan nasional pada saat sebelum dan mengakhiri pembelajaran dan melaksanakan upacara bendera. Selain itu, ada pula program penggunaan bahasa Indonesia yang baik dan benar, kunjungan ke wilayah perbatasan serta yel-yel kebangsaan juga tidak terlepas dari perhatian sekolah dalam mendukung penguatan karakter nasionalisme peserta didik. Ada pun program pembiasaan lainnya berupa keteladanan yang dilakukan oleh guru kepada peserta didik. Selanjutnya, program-program pembiasaan di SMPN Silawan tersebut dideskripsikan secara detail sebagai berikut.

\section{Menyanyikan Lagu Nasional dan Wajib Nasional Sebelum dan Mengakhiri Pem- belajaran}

Kegiatan ini merupakan kegiatan terprogram yang telah diimplementasikan oleh semua guru yang mengajar di sekolah ini. Bentuk pebiasaan ini biasanya dilakukan sebelum memulai dan mengakhiri pembelajaran. Guru akan meminta salah satu peserta didik untuk memimpin semua anggota kelas untuk bernyanyi. Permintaan ini tanpa ditunjuk ataupun adanya ketentuan giliran, namun siapa saja yang bersedia untuk memimpin maka akan dipersilahkan. Hal tersebut dilakukan dengan tujuan agar peserta didik memiliki kesadaran akan berharganya menjadi seorang pemimpin. Secara tersirat karakter nasionalisme dapat terbentuk melalui kegiatan pembiasaan ini dapat dilihat pada Tabel 1. 
Tabel 1. Karakter Nasionalisme yang Dikembangkan Melalui Pembiasaan Menyanyikan Lagu Nasional

\begin{tabular}{|c|c|c|}
\hline No. & Nasionalisme & Deskripsi \\
\hline & Mengenang jasa pahlawan & $\begin{array}{l}\text { Peserta didik dengan ketenangan menghayati setiap lirik yang di- } \\
\text { nyanyikan. }\end{array}$ \\
\hline 2. & Memahami NKRI & $\begin{array}{l}\text { Melalui lirik lagu nasional, peserta didik memahami luas wilayah } \\
\text { dan sejarah pembentukan NKRI. }\end{array}$ \\
\hline 3. & $\begin{array}{l}\text { Menggunakan produk } \\
\text { sendiri }\end{array}$ & $\begin{array}{l}\text { eserta didik menyanyikan dengan bangga lagu hasil ciptaan orang } \\
\text { donesia sendiri. }\end{array}$ \\
\hline 4. & ukan kualitas & $\begin{array}{l}\text { ou memajukan kualitas pendidikan melalui pengenalan } \\
\text { asional kepada peserta didik. }\end{array}$ \\
\hline 5. & Kebebasan berekspresi & $\begin{array}{l}\text { Peserta didik secara bebas mengekpresikan penghayatan terhadap } \\
\text { lagu nasional yang dinyanyikan. }\end{array}$ \\
\hline 6. & Apersepsi kebangsaan & $\begin{array}{l}\text { Pembelajaran dimulai dengan suasana yang menyenangkan dan } \\
\text { pembelajaran dapat dilaksanakan dengan baik. }\end{array}$ \\
\hline
\end{tabular}

Berdasarkan Tabel 1 di atas, dapat diungkapkan bahwa hal tersebut dilakukan untuk memberikan kesempatan kepada peserta didik untuk memaknai secara saksama setiap bait lagu yang dinyanyikan. Peserta didik sangat antusias menyanyikan lagu nasional dan wajib nasional. Hal tersebut dapat terlihat dari raut wajah yang sangat serius dalam menyanyikan lagu. Sepanjang nyanyian tersebut dinyanyikan, tidak ada seorang pun yang mengganggu ataupun membuat usil temen di sebelahnya. Pemandangan itu bukan karena telah diatur ataupun peserta didik yang takut akan gurunya, tetapi setiap peserta didik telah merasa terbiasa untuk selalu menghayati setiap lagu nasional yang mereka nyanyikan. Hal ini dilakukan oleh guru hampir pada setiap mata pelajaran.

\section{Upacara Bendera}

Di SMP N Silawan, kegiatan ini selain terjadi pada setiap hari senin, juga terjadi pada peringatan hari besar nasional. Kegiatan ini secara rutin diikuti oleh para guru dan juga peserta didik di sekolah tersebut. Di sekolah ini petugas upacara bendera selalu diatur teratur dan berurutan sesuai dengan tugas masing-masing. Petugas upacara bendera pada hari senin diatur berurutan sesuai dengan jenjang kelas. Setiap kelas berdiri sesuai dengan jenjang kelas, dan guru-guru berbars pada posisi yang telah disediakan. Upacara yang dilakukan di sekolah ini berjalan sesuai dengan agenda yang telah disusun secara sistematis oleh pihak sekolah. Berdasarkan hasil pengamatan, setiap peserta upacara mengikuti upacara dengan sangat baik. Karakter nasionalisme yang dikuatkan melalui pembiasaan ini dapat dijelaskan pada Tabel 2.

Berdasarkan data pada Tabel 2, dapat ditegaskan bahwa sikap menghormati atribut negara yakni bendera merah putih dan mengenang jasa para pahlawan saat mengheningkan cipta merupakan tindakan nyata berkarakter nasionalisme. Selain itu, pada setiap sambutan, pemimpin upacara selalu menegaskan tentang pentingnya menjadi warga negara yang baik. Pemimpin upacara juga selalu menegaskan bahwa sebagai seoarang peserta didik yang berada di wilayah perbatasan, sangat penting untuk selalu mencintai Indonesia dengan sepenuh hati. Rasa cinta itulah yang akan melahirkan tindakan-tindakan bela negara sebagai warga negara yang memiliki rasa setia atau loyalitas yang tinggi. 
Tabel 2. Karakter Nasionalisme yang Dikembangkan Melalui Pembiasaan Upacara Bendera

\begin{tabular}{ll}
\hline No. & \multicolumn{1}{c}{ Nasionalisme } \\
\hline 1. $\begin{array}{l}\text { Menghargai atribut } \\
\text { Negara }\end{array}$ & $\begin{array}{l}\text { Peserta didik memberikan penghormatan saat bendera merah putih } \\
\text { dikibarkan. }\end{array}$ \\
2. $\begin{array}{l}\text { Mengenang jasa para } \\
\text { pahlawan }\end{array}$ & $\begin{array}{l}\text { Peserta didik mengheningkan cipta seraya mendoakan jasa para } \\
\text { pahlawan. }\end{array}$ \\
3. Bangga menjadi Warga & $\begin{array}{l}\text { Bangga memiliki bendera putih dan lagu Indonesia raya yang } \\
\text { diciptakan oleh anak bangsa sendiri. }\end{array}$ \\
Negara Indonesia & $\begin{array}{l}\text { Peserta didik mendengarkan arahan tentang nasionalisme yang me- } \\
\text { mungkinkan mereka memperoleh informasi tambahan di luar kelas. }\end{array}$ \\
4. Amanat kebangsaan & Kesetiaan peserta didik untuk mengikuti upacara bendera juga meru- \\
5esetiaan terhadap & pakan upaya untuk meningkatkan kualitas pendidikan di sekolah. \\
\hline
\end{tabular}

\section{Penyambutan Tamu Kenegaraan di Wila- yah Perbatasan}

DiSMPN Silawan, terdapat salah satu program yang turut mendukung penguatan karakter nasionalisme peserta didik adalah penyambutan tamu kenegaraan. Program ini melibatkan peserta didik untuk berpartisipasi dalam kegiatan penyambutan tamu kenegaraan di wilayah perbatasan. Kegiatan penyambutan tamu kenegaraan ini merupakan pembiasaan yang bersifat spontan. Pelaksanaan program penyambutan ini biasanya dilaksanakan apabila dari pihak instansi perbatasan meminta sekolah berpartisipasi. Tamu kenegaraan tersebut bisa saja petinggi atau pejabat dalam negara, maupun tamu kehormatan dari luar negeri. Peserta didik yang terlibat dalam kegiatan penyambutan ini adalah peserta didik yang selalu dipersiapkan oleh sekolah dengan berbagai keahliannya. Adapun keahlian yang dimaksudkan adalah peserta didik yang pandai berbahasa daerah, drum band, dan juga penari tarian daerah. Saat tamu kenegaraan tiba di wilayah perbatasan maka langsung diterima oleh pemerintah daerah sebagai tuan rumah. Setelah itu, langsung diikuti dengan sapaaan daerah setempat yang disyairkan oleh peserta didik SMPN Silawan. Selanjutnya, karakter nasionalisme yang dapat dikuatkan melalui pembiasaan ini dapat terlihat pada Tabel 3 berikut.

Tabel 3. Karakter Nasionalisme yang Dikembangkan Melalui Pembiasaan Upacara Bendera

\begin{tabular}{|c|c|c|}
\hline No. & Nasionalisme & Deskripsi \\
\hline 1. & Menghargai keberagaman & $\begin{array}{l}\text { Peserta didik dan tamu undangan yang hadir dengan latar belakang } \\
\text { kebudayaan yang beragam seperti pakaian adat, bahasa daerah yang } \\
\text { digunakan, hingga menyaksikan tarian daerah. }\end{array}$ \\
\hline 2. & $\begin{array}{l}\text { Bangga menggunakan } \\
\text { produk sendiri }\end{array}$ & $\begin{array}{l}\text { Peserta didik secara tidak malu-malu menampilkan pakaian tenunan } \\
\text { khas daerah masing-masing. }\end{array}$ \\
\hline & $\begin{array}{l}\text { Melestarikan kebudayaan } \\
\text { daerah }\end{array}$ & $\begin{array}{l}\text { Peserta didik dilatih untuk bersyair dan mendengarkan hasehawa, } \\
\text { serta menari tarian likurai. }\end{array}$ \\
\hline & $\begin{array}{l}\text { Kesetiaan terhadap } \\
\text { lingkungan sosial }\end{array}$ & $\begin{array}{l}\text { Peserta didik mempu berinteraksi dan bersosialisasi dengan tamu } \\
\text { undangan secara baik dan melaksanakan pergaulan tanpa batas }\end{array}$ \\
\hline & $\begin{array}{l}\text { Bangga menjadi Warga } \\
\text { Negara Indonesia }\end{array}$ & $\begin{array}{l}\text { Anggota drum band memainkan lagu-lagu nasional Indonesia dengan } \\
\text { penuh semangat dan gembira. }\end{array}$ \\
\hline
\end{tabular}

Berdasarkan Tabel 3 di atas, dapat dijelaskan bahwa sapaan daerah tersebut biasanya dikenal oleh masyarakat Kabupaten Belu pada umumnya dan masyarakat 
di wilayah perbatasan pada khususnya dengan istilah hasehawaka. Penyambutan tamu kenegaraan dengan hasehawaka ini menandakan diterimanya tamu tersebut di wilayah Kabupaten Belu. Irama drum band kemudian langsung bersenandung, mengiringi kedatangan tamu kenegaraan. Irama drum band yang diperagakan oleh peserta didik ini merupakan hasil binaan SMPN Silawan. Irama drum band tersebut bertemakan lagu-lagu kebangsaan Indonesia. Program pembiasaan ini selalu menjadi kegiatan spontan yang selalu dilaksanakan oleh sekolah ketika menyambut tamu kenegaraan di wilaah perbatasan. Hal ini dilakukan untuk memberikan pengenalan kepada peserta didik tentang aktivitas kenegaraan di wilayah perbatasan. Selain itu, partisipasi ini juga memberikan rasa nyaman kepada peserta didik di wilayah perbatasan bahwa kontirbusi mereka sangat dibutuhkan. Untuk itu peran dari sekolah yang terintegrasi dalam program ini sangat membantu peserta didik dalam proses penguatan karakter nasionalisme mereka. Peserta didik akan menerima keberagaman di sekitar mereka dan mencintai perbedaan di antara sesama.

\section{Penggunaan Bahasa Indonesia}

Di SMP Silawan, ada pembiasaan menggunakan Bahasa Indonesia yang baik dan benar yang dijadwalkan secara khusus. Hal ini dilakukan dengan alasan bahwa peserta didik yang bersekolah di SMPN Silawan sulit untuk meninggalkan bahasa asli mereka, yakni Bahasa Tetun yang dikolaborasikan dengan dialek Timor Leste. Berdasarkan pengamatan dan hasil wawancara dengan beberapa guru, maka dapat disimpulkan bahwa pada mulanya peserta didik sulit untuk beradaptasi dengan pembiasaan ini. Karakter nasionalisme yang dapat dikuatkan melalui kegiatan pembiasaan ini dapat ditegaskan pada Tabel 4 .

\section{Tabel 4. Karakter Nasionalisme yang Dikembangkan melalui Pembiasaan Penggunaan Bahasa Indonesia}

\begin{tabular}{|c|c|c|}
\hline No. & Nasionalisme & Deskripsi \\
\hline 1. & $\begin{array}{l}\text { Berkomunikasi } \\
\text { menggunakan Bahasa } \\
\text { Indonesia yang baik dan } \\
\text { sopan }\end{array}$ & $\begin{array}{l}\text { Peserta didik menjadikan Bahasa Indonesia sebagai bahasa } \\
\text { utama dalam berkomunikasi dengan seluruh perangkat sekolah } \\
\text { sejak masuk hingga pulang sekolah. }\end{array}$ \\
\hline 2. & $\begin{array}{l}\text { Menghargai perbedaan } \\
\text { pendapat }\end{array}$ & $\begin{array}{l}\text { Peserta didik menjadi pendengar yang baik dan berusaha saling } \\
\text { mendengarkan satu sama lainnya saat berbicara. }\end{array}$ \\
\hline 3. & $\begin{array}{l}\text { Menggunakan produk } \\
\text { sendiri }\end{array}$ & $\begin{array}{l}\text { Peserta didik menjadikan Bahasa Indonesia sebagai bahasa yang } \\
\text { mempersatukan mereka dari berbagai bahasa saat berbicara. }\end{array}$ \\
\hline 4. & $\begin{array}{l}\text { Penghargaan terhadap } \\
\text { lingkungan sosial }\end{array}$ & $\begin{array}{l}\text { Peserta didik melaksanakan interaksi dengan seluruh stake holder } \\
\text { sekolah untuk memperoleh informasi dimana saja. }\end{array}$ \\
\hline 5. & $\begin{array}{l}\text { Menjunjung Bahasa } \\
\text { Indonesia }\end{array}$ & $\begin{array}{l}\text { Walaupun masih fasih berbicara berbahasa Timor Leste, peserta } \\
\text { didik tetap memilih untuk menggunakan Bahasa Indonesia saat } \\
\text { beraktivitas di sekolah. }\end{array}$ \\
\hline 6. & Mempererat persatuan & $\begin{array}{l}\text { Peserta didik melaksanakan pembelajaran dalam kelompok } \\
\text { untuk memperat persatuan. }\end{array}$ \\
\hline
\end{tabular}

Berdasarkan Tabel 4 di atas, ditegaskan bahwa setiap hari peserta didik harus terbiasa menggunakan Bahasa Indonesia sejak memasuki wilayah sekolah hingga saat pulang sekolah. Terlepas dari itu maka pada hari senin hingga jumat terkecuali hari kamis, penggunaan Bahasa Indonesia yang baik dan benar di lingkungan sekolah 
harus diaktualisasikan. Selain itu, bahasa merupakan salah satu alat pemersatu Bangsa Indonesia yang harus dijunjung tinggi oleh Warga Negara Indonesia.

\section{Yel-yel Kebangsaan}

Pembiasaan yel-yel kebangsaan rutin dilaksanakan saat apel pagi dan siang saat pulang sekolah. Yel-yel ini dibuat khusus oleh sekolah dalam rangka menguatkan karakter nasionalisme peserta didik di wilayah perbatasan. Selain menjadi kekhasan dari SMPN Silawan, yel-yel kebangsaan ini merupakan satu-satunya kegiatan pembiasaan yang membedakan dengan sekolah lainnya. Proses penguatan karakter nasionalisme melalui pembiasaan ini terlihat pada Tabel 5 .

Tabel 5. Karakter Nasionalisme yang Dikembangkan Melalui Pembiasaan Yel-Yel Kebangsaan

\begin{tabular}{|c|c|c|}
\hline No. & Nasionalisme & Deskripsi \\
\hline 1. & $\begin{array}{l}\text { Kesetiaan terhadap } \\
\text { lingkungan fisik }\end{array}$ & $\begin{array}{l}\text { Peserta didik dilatih melalui syair yang disoraki untuk bisa setia } \\
\text { terhadap lingkungan tempat tinggal khususnya sebagai anak batas. }\end{array}$ \\
\hline 2. & $\begin{array}{l}\text { Menguatkan } \\
\text { kebersamaan }\end{array}$ & $\begin{array}{l}\text { Peserta didik dilatih untuk bisa memahami kebersamaan mereka } \\
\text { sebagai anak batas melalui janji kesetiaan dalam yel-yel kebangsaan }\end{array}$ \\
\hline 3. & $\begin{array}{l}\text { Kebebasan } \\
\text { berekpresi }\end{array}$ & $\begin{array}{l}\text { Peserta didik menyorakan yel-yel kebangsaan dengan ekspresi yang } \\
\text { beragam sesuai dengan kebebasan menikmati aktivitas tersebut. }\end{array}$ \\
\hline 4. & $\begin{array}{l}\text { Bangga sebagai } \\
\text { Warga Negara } \\
\text { Indonesia }\end{array}$ & $\begin{array}{l}\text { Melalui sorakan yang semangat, peserta didik dilatih untuk bangga } \\
\text { menjadi Warga Negara Indonesia walaupun tinggal di perbatasan. }\end{array}$ \\
\hline
\end{tabular}

Berdasarkan Tabel 5 di atas, dapat dijelaskan bahwa pembiasaan yel-yel kebangsaan ini secara rutin dilaksanakan setiap hari setelah selesai pengarahan atau himbauan dari kepala sekolah maupun salah satu guru. Berdasarkan hasil pengamatan, peserta didik di SMPN Silawan sangat antusias dalam menyoraki yel-yel ini. Setiap peserta didik dengan semangat yang membara meneriaki yel-yel bersama dengan teman-teman lainnya. Melalui wawancara dengan beberapa peserta didik diperoleh kesimpulan bahwa mereka memiliki kesetiaan yang tinggi terhadap lingkungan fisik.

\section{Keteladanan Guru}

Program penguatan karakter yang diimplementasikan oleh pemerintah me- lalui kementerian pendidikan memiliki kontribusi yang sangat berpengaruh terhadap kehidupan guru di sekolah. Di SMPN Silawan, hal ini menjadi perhatian khusus oleh pihak sekolah khususnya para guru. Pemberian keteladanan ini merupakan salah satu program pembiasaan yang diselenggarakan oleh pihak sekolah dalam rangka mencapai tujuan tertentu. Salah satu yang menjadi tujuan utama dari keteladanan para guru SMPN Silawan adalah membentuk kepribadian yang nasionalis. Proses penguatan karakter nasionalisme melalui pembiasaan ini dapat terlihat pada Tabel 6. 
Tabel 6. Karakter Nasionalisme yang Dikembangkan Melalui Pembiasaan Keteladanan Guru

\begin{tabular}{|c|c|c|}
\hline No. & Nasionalisme & Deskripsi \\
\hline 1. & $\begin{array}{l}\text { Berkomunikasi yang } \\
\text { sopan }\end{array}$ & $\begin{array}{l}\text { Para guru memberikan teladan dengan berkomunikasi yang sopan } \\
\text { kepada setiap stake holder sekolah. }\end{array}$ \\
\hline 2. & $\begin{array}{l}\text { Melestarikan } \\
\text { kebudayaan daerah }\end{array}$ & $\begin{array}{l}\text { Para guru menggunakan tais atau dalam Bahasa Indonesia berarti } \\
\text { kain adat beserta pernak-perniknya. }\end{array}$ \\
\hline 3. & Menjalin persahabatan & $\begin{array}{l}\text { Dalam proses sosialisasi keseharian di sekolah, para guru terlihat } \\
\text { sangat akrab dan bersahaja antar satu dan lainnya. }\end{array}$ \\
\hline 4. & $\begin{array}{l}\text { Kesetiaan terhadap } \\
\text { Bangsa }\end{array}$ & $\begin{array}{l}\text { Para guru selalu disiplin dalam mengajar dan tetap memberikan } \\
\text { dedikasi maksimal bagi perkembangan karakter anak batas. }\end{array}$ \\
\hline 5. & $\begin{array}{l}\text { Kepentingan bangsa } \\
\text { menjadi utama }\end{array}$ & $\begin{array}{l}\text { Guru memajukan kualitas pendidikan melalui dedikasinya sebagai } \\
\text { pendidik dan menikmati setiap tempat sebagai kelas pembelajaran }\end{array}$ \\
\hline 6. & $\begin{array}{l}\text { Mengutamakan } \\
\text { persatuan }\end{array}$ & $\begin{array}{l}\text { Guru memberikan kesempatan kepada peserta didik untuk } \\
\text { berpendapat dan menempatkan kebenaran sebagai sesuatu yang } \\
\text { subjektif }\end{array}$ \\
\hline
\end{tabular}

Berdasarkan Tabel 6 di atas, dapat diungkapkan bahwa pemberian teladan tersebut merupakan salah satu kebijakan yang diimplementasikan oleh kepala sekolah dalam rangka mendukung proses penguatan karakter nasionalisme peserta didik. Para guru diwajibkan untuk berbicara Bahasa Indonesia yang baik dan benar sejak memasuki wilayah sekolah hingga pulang. Selain itu, setiap pelaksanaan upacara bendera setiap guru wajib wajib mengikuti proses pelaksanaan dari awal hingga akhir dengan penuh ketenangan. Di samping itu, setiap guru wajib menggunakan produk dalam negeri seperti kain tenunan ataupun selendang. Setiap pemberian suri teladan ini sesungguhnya merupakan strategi sekolah dalam memberikan teladan yang baik kepada para penerus bangsa ini. Setiap perilaku teladan yang diikuti akan berbuah manis apabila pelaku teladannya memberikan tolok ukur yang pantas untuk ditiru. Di SMPN Silawan, hal ini diyakini sebagai sesuatu yang sangat penting untuk dilaksanakan. Dampak dari pelaksanaan program ini terlihat sesuai indikator pencapaian keberhasilan yang diharapkan oleh sekolah.

\section{Pembahasan}

Di antara kedelapan pembiasaan di atas, tentu semuanya memiliki peran dan kontribusi yang sangat penting. Peran dan kontribusi dari pembiasaan tersebut sangat membantu menguatkan karakter nasionalisme peserta didik. Sekolah sebagai suatu wadah pembentukan karakter warga negara tentunya dalam hal ini telah menjalankan tugasnya dengan baik. SMPN Silawan telah melaksanakan suatu proses penguatan karakter nasionalisme melalui pengintegrasian program pembiasaan di sekolah. Melalui program-program kegiatan pembiasaan di atas, dapat terlihat bahwa para peserta didik sangat menikmatinya. Hal tersebut nampak pada antusiasme peserta didik dalam proses pelaksanaannya. Sekolah juga sebagai pihak penyelenggara selalu memberikan kebijakan untuk memotivasi ataupun stimulus untuk merangsang peserta didik. Kebijakan tersebut telah disepakati secara bersama oleh pihak sekolah guna menciptakan iklim pembiasaan yang menyenangkan. Berkaitan dengan itu maka SMPN Silawan telah melaksanakan sesuatu yang benar. Sebagaimana diungkapkan Aqib (2014:30) menegaskan bahwa karakter merupakan nilai-nilai yang terpatri dalam 
diri melalui pendidikan, pola asuh, pengalaman, percobaan, pengorbanan, dan pengaruh lingkungan menjadi nilai intrinsik yang melandasi sikap dan perilaku.

Pelaksanaan program pembiasaan ini melibatkan partisipasi aktif dari semua perangkat sekolah tanpa terkecuali. Selain itu, instansi-instansi yang terkait dalam ranah pembiasaan ini pun tidak luput dari kerja sama mereka. Bentuk kolaborasi sekolah dengan lembaga terkait ini menghasilkan suatu efektivitas pelaksanaan program pembiasaan yang baik. Hal itu nampak pada beberapa program pembiasaan yang melibatkan pelatih atau pendamping khusus yang memiliki keahlian pada bidangnya. Peserta didik selalu menantikan pelaksanaan program pembiasaan dalam kesehariannya di sekolah. Melihat hal tersebut maka pihak sekolah selalu berusaha untuk menciptakan efektivitas pelaksanaan program pembiasaan ini dengan baik. Pembiasaan ini berbanding lurus dengan pandangan Giddens (Saptono, 2011:58) yang menyatakan bahwa kebiasaan itu menciptakan struktur hidup sehingga memudahkan orang untuk bertindak; melalui habitus, orang tak perlu susah payah bernalar, mengambil jarak atau memberi makna setiap kali hendak bertindak.

Berdasarkan hasil wawancara dengan para guru dan tokoh masyarakat maka dapat disimpulkan bahwa terjadi perubahan perilaku yang sangat signifikan dari peserta didik. Melalui proram pembiasaan ini, peserta didik secara tidak sengaja telah mempraktikan kebiasaan berperilaku. Pembiasaan berperilaku nasionalis ini diajarkan di sekolah melalui suatu proses pelaksanaan program pembiasaan. Di samping itu, dalam kehidupan sehari-hari baik di sekolah maupun di rumah peserta didik selalu mempraktikannya bersama teman-temanya. Tentunya hal tersebut sangat ber- pengaruh juga terhadap perilaku teman sebaya. Sebagaimana diungkapkan bahwa karakter dapat diartikan sebagai suatu keadaan mengetahui, peduli dan bertindak atas nilai-nilai etika, dan menghormati diri sendiri dan orang lain (Berkowitz \& Fekula, 1999). Terlepas dari itu, pemberian teladan yang baik dari guru pun memberikan manfaat yang luar biasa. Hal tersebut sependapat dengan pandangan bahwa keteladanan guru memiliki posisi yang cukup urgent melalui pembiasaan dalam pendidikan karakter (Asmani, 2012). Hal itu dipertegas oleh Azzet (2014:13) bahwa sebagus apa pun karakter yang dibangun dalam lembaga pendidikan apabila tidak ada suri teladan dari para pendidiknya, akan sulit dapat tercapai apa yang telah diharapkan.

Peserta didik secara teratur telah mampu berbahasa Indonesia yang baik dan benar. Dengan adanya kemampuan berbahasa Indonesia ini maka secara perlahan penggunaan bahasa Timor Leste dalam kehidupan sehari-hari mulai perlahan diminimalisir. Hal ini bukan berarti bahwa peserta didik dipaksa untuk melupakan bahasa daerahnya, melainkan menjadikan Bahasa Indonesia sebagai bahasa persatuan dan bahasa daerah sebagai kekayaannya. Terlepas dari itu peserta didik juga telah terbiasa mengkonsumsi makanan produk lokal buatan dalam negeri. Adapun hal lain yang nampak dari peserta didik adalah adanya rasa bangga menggunakan pakaian buatan dalam negeri. Perilaku ini tentunya sependapat dengan Samani dan Hariyanto (2012:41) yang memaknai karakter sebagai cara berpikir dan berperilaku yang khas tiap individu untuk hidup dan bekerja sama, baik dalam lingkup keluarga, masyarakat, bangsa dan negara.

Tentunya pandangan di atas sangat erat kaitannya dengan proses penguatan 
karakter nasionalisme. Sebagaimana diungkapkan oleh Kementerian Pendidikan dan Kebudayaan (Komalasari dan Saripudin, 2017) bahwa karakter nasionalis merupakan kesatuan cara berpikir, bersikap, dan bertingkah laku yang menampilkan kesetiaan, penghargaan yang tinggi terhadap bahasa, lingkungan fisik, sosial, budaya, ekonomi, dan politik bangsa, serta menempatkan kepentingan bangsa dan negara di atas apapun. Terlepas dari itu, untuk menguatkan karakter nasionalisme peserta didik, maka harus dilakukan suatu proses yang dapat menantang jiwa nasionalisme mereka. Pandangan tersebut beralasan bahwa sebuah bangsa akan terbentuk ketika masyarakat merespon positif terhadap setiap tantangan yang menguji rasa nasionalisme warga negaranya (Gonzalez-torres \& Fernandez-rivas, 2014 \& Maxwell, 2018).

Pembiasaan berkarakter nasionalisme ini sesungguhnya merupakan produk dari pembiasaan yag dilakukan di sekolah. Alfiky (Anwar, 2014) mengungkapkan bahwa kebiasaan adalah suatu pola pikir yang telah tertanam dalam diri seseorang, kemudian dikorelasikan dengan keinginan untuk melakukannya secara berulang-ulang hingga akal meyakinya sebagai indikator dari perilakunya. Pembiasaan inilah yang akan berpengaruh terhadap tindakan peserta didik saat bertumbuh di masa depan. Sebagaimana disimpulkan oleh Amirulloh (2015) bahwa pembiasaan yang dilakukan oleh seseorang akan menjadi suatu kebiasaan yang memainkan peranan sangat penting bagi kehidupan seorang anak di masa depan. Dapat dikemukakan bahwa keberhasilan program pembiasaan dalam menguatkan karakter nasionalisme peserta didik di SMPN Silawan terjadi karena efektifnya beberapa pendekatan. Sebagaimana diungkapkan bahwa pendekatan yang dilakukan dalam pelaksanaan pendidikan nasionalisme me- lalui pembiasaan dapat dilakukan melalui kegiatan rutin, kegiatan spontan, kegiatan pemberian keteladanan dan kegiatan terprogram (Anwar, 2014).

\section{PENUTUP}

Berdasarkan hasil penelitian dan pembahasan di atas dapat dikemukakan beberapa simpulan sebagai berikut. Pertama, proses penguatan karakter nasionalisme peserta didik di wilayah perbatasan dapat dilakukan melalui program pembiasaan. Program pembiasaan tersebut dapat berupa pelaksanaan upacara bendera, pengguanaan Bahasa Indonesia yang baik dan benar, kunjungan ke wilayah perbatasan, yel-yel kebangsaan, menyanyikan lagu kebangsaan saat memulai dan mengakhiri pembelajaran hingga keteladanan dari seorang guru.

Kedua, penguatan karakter nasionalisme melalui program pembiasaan memiliki manfaat dan kontirbusi yang sangat penting. Hal tersebut dapat terlihat dari perubahan sikap dan perilaku yang dipraktikkan oleh peserta didik di lingkungan sekolah maupun dalam pergaulan sehari-hari. Perubahan pola sikap dan perilaku ini menunjukkan bahwa program pembiasaan di lingkungan sekolah memberikan kontribusi yang sangat banyak dalam proses penguatan karakter nasionalisme peserta didik.

Ketiga, adanya suri teladan dari para guru di sekolah juga memberikan kontribusi yang sangat penting. Keteladanan yang dipraktikkan oleh para guru di lingkungan SMPN Silawan ternyata memberikan manfaat yang baik bagi para peserta didik. Keteladanan ini dijadikan contoh bagi peserta didik dalam mendukung proses penguatan karakter nasionalisme. Adanya ketegasan dari pimpinan sekolah pun sangat dibutuhkan untuk memberikan motivasi dan 
juga ransangan bagi para guru dalam memberikan teladan yang baik.

\section{UCAPAN TERIMA KASIH}

Ucapan terima kasih penulis sampaikan kepada dosen pembimbing akademik yang telah memberikan koreksi dan saran dalam penulisan karya ilmiah ini. Selain itu, ucapan terima kasih juga disampaikan kepada teman-teman dari Departemen Pendidikan Kewarganegaraan Pascasarjana Universitas Pendidikan Indonesia Angkatan 2017, yang telah memberikan semangat sehingga penulisan ini dapat diselesaikan tepat pada waktunya.

\section{DAFTAR PUSTAKA}

Abdillah, F. (2018). Mendidik warga negara indonesia di sekolah dasar: Perspektif guru. Jurnal Inspirasi Pendidikan, 8(2), 60-67. DOI: 10.21067/jip.v8i2.2643.

Amirulloh, H. (2015). Teori pendidikan karakter remaja dalam keluarga. Bandung: Alfabeta.

Anwar, C. (2014). Internalisasi semangat nasionalisme melalui pendekatan habituasi. Jurnal Studi Keislaman, 14(1), 159 - 172. DOI: 10.24042/ajsk.v14i1.653.

Aqib, Z. \& Sujak. (2011). Panduan dan aplikasi pendidikan karakter. Bandung: Yrama Widya.

Aqib, Z. (2014). Pendidikan karakter: Membangun perilaku positif anak bangsa. Bandung: Yrama Widya.

Asmani, J.M. (2012). Buku panduan internalisasi pendidikankarakterdi sekolah.Cetakan Kelima. Yogyakarta: Diva Press.
Azzet, A.M. (2014). Urgensi pendidikan karakter di Indonesia. Yogyakarta: Ar Ruzz Media.

Bański, J. \& Janicki, W. (2013). The influence of the EU's eastern frontier on the socioeconomic situation of border areas. European Urban and Regional Studies, 20(3), 299 -313. DOI: 10.1177/0969776411432991.

Berkowitz, B.M.W. \& Fekula, M.J. (1999). Educating for character. About Campus: Enriching the Student Learning Experience, 4(5), 17-22.

Conger, J. A., \& Xin, K. (2000). Executive education in the 21st century. International Journal of Listening, 14(1), 73-101. DOI: $10.1177 / 105256290002400106$.

Creswell, J. (2015). Riset pendidikan: Perencanaan, pelaksanaan, dan evaluasi riset kualitatif $\mathcal{E}$ kuantitatif. Yogyakarta: Pustaka Pelajar.

Dyson, M. (2010). What might a personcentred model of teacher education look like in the 21st century? The transformism model of teacher education. Journal of Transformative Education, 8(1), 3-21. DOI: 10.1177/1541344611406949 .

Gonzalez-torres, M. A., \& Fernandez-rivas, A. (2014). Some reflections on nationalism, identity and sexuality. International Forum of Psychoanalysis, 23(3), 135-143. DOI: 10.1080/0803706X.2013.794958.

Haselsberger, B. (2014). Decoding borders. Appreciating border impacts on space and people. Planning Theory and Prac- 
tice, 15(4), 505-526. 10.1080/14649357.2014.963652.

Hermuttaqien, B.P.F., Sata, H.R., \& Wadu, L.B. (2019). Perbandingan pembelajaran PPKn pada implementasi KTSP dan kurikulum 2013 di Sekolah Menengah Pertama (SMP). Jurnal Inspirasi Pendidikan, 9(1), 39-44. DOI: http://dx.doi.org/ 10.21831.

Hjerm, M. (2010). Education, xenophobia and nationalism: A comparative analysis. Journal of Ethnic and Migration Studies, 27(1), 37-60. DOI: 10.1080/13691830124482.

Holm, L., \& Horn, C. (2003). Bridging the gapbetween schools of education and the needs of 21st-century teachers. Phi Delta Kappan, 84(5), 376-380. DOI: 10.1177/003172170308400511.

Kirom, S. (2018). Penguatan Karakter Diri Melalui Pembelajaran Drama. Jurnal Inspirasi Pendidikan, 8(1), 40-52.

Komalasari, K. \& Saripudin, D. (2017). Pendidikan karakter: Konsep dan aplikasi living values education. Bandung: Refika Aditama.

Maxwell, A. (2018). Nationalism as classification: Suggestions for reformulating nationalism research. Nationalities $\mathrm{Pa}$ pers, 46(4), 539-555. DOI: 10.1080/00905992.2018.1448376.

Misra, S. (2013). Border and bordering practices from the cinematic lens. International Studies, 50(1-2), 35-54. DOI: $10.1177 / 0020881716654383$.
Muchtarom, M., Budimansyah, D., \& Suryadi, A. (2016). The implementation of integrated education to develop the intact personality of students. The New Educational Review, 43(1), 147156. DOI: 10.15804/tner.2016.43.1.12.

Mulyasa, H.E. (2015). Revolusi mental dalam pendidikan. Bandung: PT Remaja Rosdakarya.

Muslich, M. (2013). Pendidikan karakter: Menjawab tantangan krisis multidimensional. Jakarta. Bumi Aksara.

Permatasari, A. (2014). Otonomi khusus daerah perbatasan, alternatif solusi penyelesaian masalah perbatasan di Indonesia. Jurnal Media Hukum, 21(2), 226-240. URL: http://journal.umy.ac.id/index.php/jmh/article/view/1 189.

Pureklolon, T.T. (2017). Nasionalisme: Supremasi perpolitikan negara. Jakarta: PT Gramedia Pustaka Utama.

Sahlan, A. \& Prastyo, A.T. (2017). Desain pembelajaran berbasis pendidikan karakter. Yogyakarta: Ar - Ruzz Media.

Saleh, M.H. (2011). Model pemaknaan nasionalisme masyarakat Pulau Sebatik Kalimantan Timur. Borneo Administrator, 7(2), 202-221. DOI: doi.org/10.24258/jba.v7i2.74.

Samani, M \& Hariyanto. (2012). Pendidikan karakter: Konsep dan model. Bandung: PT Remaja Rosdakarya.

Saptono. (2011). Dimensi-dimensi pendidikan karakter: wawasan, strategi dan langkah praktis. Jakarta: Erlangga. 
Sassler, S. (2018). Families in the 21 st century. Contemporary Sociology: A Journal of Reviews, 47(2), 177-178. DOI: 10.1177/0094306118755396k.

Schack, M. (2001). Regional identity in border regions: The difference borders make. Journal of Borderlands Studies, 16(2), 99-114. DOI: 10.1080/08865655.2001 .9695576 .

Schunk, D.H. (2012). Teori-teori pembelajaran: Perspektif pendidikan. Yogyakarta. Pustaka Belajar.

Sulistyawati, P., Sunnah, V. H., \& Setiawan, D. A. (2018). Kajian pendidikan karakter berbasis religi dalam menangani problematika kenakalan anak SDN Gadang 1 Malang. Jurnal Inspirasi Pendidikan, 8(2), 37-44. DOI:10.21067/jip.v8i2.2639.
Taufik. (2014). Pendidikan karakter di sekolah: Pemahaman, metode penerapan, dan peranan tiga elemen. Jurnal Ilmu Pendidikan, 20(1), 59-65. DOI: 10.17977/jip.v20i1.4378.

Vinokur, E. (2018). Cosmopolitan education in local settings: toward a new civics education for the 21st century. Policy Futures in Education, 0(0), 1-21. DOI: $0.1177 / 1478210318775516$.

Walters, W. (2006). Border/control. European Journal of Social Theory, 9(2), 187203. DOI: $10.1177 / 1368431006063332$. 